\title{
Aktivitas Fisik Masyarakat Urban di Jakarta Selatan
} Irma Guspita Dewi', Caroline Endah Wuryaningsih ${ }^{2}$

1,2 Departement Pendidikan Kesehatan dan Ilmu Perilaku Fakultas Kesehatan Masyarakat Universitas Indonesia, Jl. Prof, Dr. Sujudi, Pomdok Cina, Kota Depok, Jawa Barat, irma.guspita@gmail.com

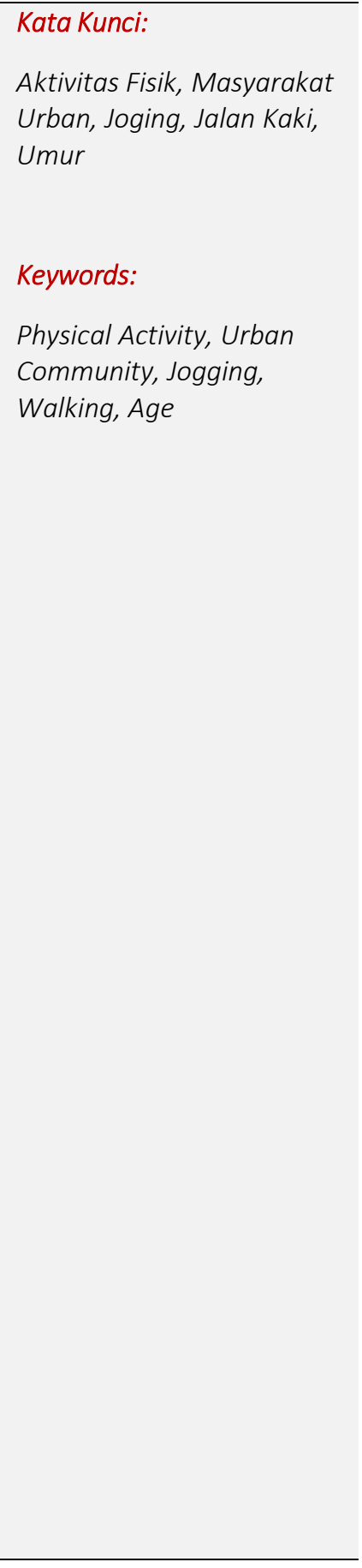

\section{ABSTRAK}

Salah satu faktor risiko yang dapat menyebabkan kematian adalahkurangnya aktivitas fisik oleh karena meningkatkan risiko penyakit jantung, diabetes melitus, dan hipertensi. Aktivitas fisik berdampak positif terhadap keseimbangan energi dan pengendalian berat badan. Penelitian ini bertujuan mendapatkan gambaran aktivitas fisik penduduk di wilayah urban dan kaitannya dengan umur seseorang. Penelilitian ini menggunakan rancangan penelitian cross sectional study dan pengambilan data dilakukan pada bulan Mei-Juni 2018 yang berlokasi di kawasan urban dan padat penduduk di Kelurahan Lenteng Agung, Kota Administrasi Jakarta Selatan, Provinsi DKI Jakarta dengan sampel sebanyak 123 orang. Teknik pengambilan sampel dalampenelitian ini menggunakan teknik purposive sampling dan pengumpulan data menggunakan wawancara kusioner. Hasil penelitian menunjukkan bahwa rata-rata umur responden dalam penelitian ini berusia 41,8 tahun dan aktivitas fisik yang paling banyak dilakukan adalah jalan kaki (67 \%). Hanya aktivitas joging yang memiliki hubungan yang signifikan dengan umur (nilai $p=0,003$ ) dan lama senam $(p=0,036)$. Perlu dilakukan upaya peningkatkan sarana dan prasarana olahraga sesuai dengan kelompok umur serta promosi dan edukasi mengenai aktivitas fisik agar pengetahuan dan partisipasi masyarakat untuk aktif bergerak meningkat.

\section{ABSTRACT}

Lack of physical activity is one of the risk factors that cause death in the world. The risk of heart disease, diabetes mellitus and hypertension can be reduced by performing regular physical activity. In addition, the positive impact is on energy balance and weight control. The aim of this study was to obtain the overview of physical activity of the population within urban areas and its relation to their age. This study used a cross-sectional design and data collection was conducted in May-June 2018, located in urban and densely populated areas in Lenteng Agung, South Jakarta Administrative City, Jakarta Province with a sample of 123 respondents. The sampling technique used in this study was purposive sampling and data collection employed questionnaire interviews. This study found that the average age of respondents in this study indicated 41.8 years old and the most common physical activity carried out was walking (67\%). Only jogging activity has a significant relationship with age ( $p$-value $=0.003)$ and gymnastics exercise time ( $p$-value $=0.036)$. An effort needs to be made to improve sports facilities and infrastructure in accordance to age groups, and to promote and educate regarding physical activities in order to increase community knowledge and participation.

Copyright (C) 2019 HaJoM. All rights reserved 


\section{Latar Belakang}

Kurang melakukan aktivitas fisik merupakan salah satu faktor risiko penyebab kematian di dunia. Permasalahan ini menjadi perhatian pemerintah di banyak negara (Purwanto, 2011). Menurut WHO (2018), terdapat peningkatan risiko kematian sebesar 20\%-30\% pada orang dengan kurang melakukan aktivitas fisik dibandingkan dengan aktif melakukan latihan fisik selama minimal 150 menit dengan intensitas sedang per minggu secara rutin. Hal tersebut disebabkan oleh beberapa faktor seperti populasi yang menua (lanjut usia) dan gaya hidup yang kurang melakukan aktivitas fisik (Minh et al., 2015).

Bertambahnya umur akan mempengaruhi aktivitas fisik seseorang. Sebagaimana hasil temuan Sulistiono(2015), umur merupakan dapat mempengaruhi kualitas dan kuantitas aktivitas fisik seseorang yang terkait dengan aktivitas fisik sehari-hari. Hal ini disebabkan karena bertambahnya umur akan disertai dengan penurunan kapasitas fisik berupa penurunan masa dan kekuatan otot, laju denyut jantung maksimal, peningkatan lemak tubuh, dan penurunan fungsi otak (Junaidi, 2011). Perkembangan tubuh terhenti sehingga tidak akan terjadi peningkatan kualitas fisik lagi. Hal tersebut juga berakibat pada sistem pernafasan karena elastisitas recoil paru menjadi berkurang sehingga berpengaruh pada volume udara yang dihirup dan dikeluarkan (Skloot, 2017). Jumlah udara yang dihirup akan menurunkan kemampuan fisik untuk melakukan aktivitas berat seperti olahraga. Hal ini dibuktikan dalam penelitian yang dilakukan oleh Wooet al. (2006) dan faktor umur memiliki pengaruh dalam penurunan kemampuan aktivitas fisik seseorang. Oleh sebab itu, orang yang berusia lanjut memiliki kecenderungan yang kurang untuk melakukan aktivitas fisik dan rentan dengan penyakit. Padahal, aktivitas fisik seperti berolahraga merupakan langkah pencegahan primer untuk menurunkan kejadian suatu penyakit.

Dalam banyak penelitian, kebalikan dari aktifmelakukan aktivitas fisik, kurang bergerak (sedentary activity) dapat memicu terjadinya penyakit seperti penyakit tidak menular (PTM). Suter et al.(1990) dalam laporannya menemukan bukti bahwa melakukan aktivitas fisik dapat menurunkan risiko penyakit terkait dengan kardiovaskuler. Azhariet al.(2009) dalam observasinya menyatakan bahwa kurang melakukan aktivitas fisik dapat meningkatkan risiko obesitas. Ortleppet al.(2004) menemukan hasil bahwa terdapat hubungan antara aktivitas fisik dengan tekanan darah dan menjadi faktor pencetus terjadinya penyakit hipertensi.

Di Indonesia, prevalensi PTM mengalami peningkatan setiap tahunnya. Menurut hasil penelitian RISKEDAS, prevalensi penyakit stroke mengalami peningkatan dari rasio 8,3 per1000 penduduk pada tahun 2007 menjadi 12,1 per1000 penduduk pada tahun 2013 secara nasional. Demikian juga untuk diabetes melitus mengalami peningkatan dari 1,1 persen (2007) menjadi 2,1 persen (2013). Prevalensi penyakit tersebut terus meningkat seiring dengan bertambahnya umur seseorang (Balitbang Kemkes RI, 2013). Ditambah lagi, menurutjumlah kejadian penyaitpada laporan 10 penyakit terbanyak di lokasi penelitian (Jagakarsa, Jakarta Selatan), penyakit PTM seperti hipertensi merupakan penyakit nomor tiga yang paling banyak diderita oleh masyarakat pada tahun 2015 (4.423 penderita). Kemudian, angkanya meningkat dan menempati penyakit nomor dua paling banyak diderita pada tahun 2016 (15.056 penderita) dan 2017 (19.426 penderita) (Puskemas Jagakarsa, 2017).

Upaya yang dilakukan untuk mereduksi kejadian PTM adalah salah satunya dengan melakukan aktivitas fisik. Aktivitas seperti joging, bersepeda, dan senam akan meningkatkan HDL kolesterol (kolesterol baik) dan menurunkan LDL kolesterol (kolesterol jahat) sehingga dapat mencegah penyakit jantung(Purwanto, 2011). Begitu juga halnya dengan penderita 
diabetes mellitus, kadar glukosa dalam darah akan mengalami penurunan dengan aktivitas fisik pada intensitas sedang. Dengan melakukan aktivitas fisik dapat meningkatkan aliran darah dan suplai oksigen ke otak sehingga berdampak pada menurunkan tingkat stres maupun tekanan darah(Purwanto, 2011; Surbakti, 2014). Kadar garam di otak keluar melalui keringat sehingga menurunkan kadar garam di otak akan memperbaiki suasana hati (Purwanto, 2011).

Selain itu, aktivitas fisik memiliki dampak positif terhadap keseimbangan energi dan pengendalian berat badan. Sehingga, tingkat kebugaran dan produktivitas individu menjadi meningkat karena tubuh berfungsi secara efektif dan memiliki energi yang cukup (Novanda \& Dwiyanti, 2014; Palar, Wongkar, \& Ticoalu, 2015). Oleh karena itu, berdasarkan fakta-fakta yang telah disebutkan sebelumnya dianggap penting dilakukan pengukuran apakah aktivitasaktifitas fisik pada masyarakat memiliki hubungan dengan umur responden. Selain itu, diharapkan juga mendapatkan gambaran jenis aktivitas fisik apa yang paling banyak banyak dilakukan oleh responden di lokasi penelitian.

\section{Metode}

Penelitian ini menggunakan rancangan cross sectional study dan pengambilan data dilakukan pada bulan Mei-Juni 2018. Lokasi penelitian berada di kawasan urban dan padat penduduk di Kelurahan Lenteng Agung, Kecamatan Jagakarsa, Kota Administrasi Jakarta Selatan, Provinsi DKI Jakarta. Melalui penelitian ini diharapkan mendapatkan gambaran aktivitas fisik dan kaitannya dengan umur seseorang di wilayah urban di Jakarta Selatan.

Besaran sampel dalam penelitian ini menggunakan rumus estimasi proporsi dengan jumlah sampel 92 orang. Untuk menghindari drop out, jumlah tersebut dibulatkan menjadi 123 orang.Teknik pengambilan sampel dalampenelitian ini menggunakan teknik purposive sampling. Responden terpilih hanya diambil satu orang/rumah, jika terdapat lebih dari satu calon reponden yang sesuai dengan kriteria penelitian dengan cara dikocok. Adapun kriteria inklusi pada penelitian ini adalah penduduk yang bermukim minimal 2 tahun di lokasi penelitian dan berusia minimal 17 tahun. Kriteria eksklusi pada penelitian ini adalah individudalam keadaan sakit.

Pengumpulan data responden dilakukandengan menggunakan wawancara kusioner untuk mendapatkan data umur dan aktivitas yaitu kebiasaan jalan kaki, kebiasaan jogging (jalan pelan-pelan atau lari pelan-pelan), aktivitas bersepeda, dan aktivitas senam. Adapun aktivitas fisik dalam penelitian ini adalah aktivitas yang dilakukan dalam rentang waktu satu minggu sebelumnya pada saat pengumpulan data (sekurangnya 30 menit dalam sehari dengan kuantitas minimal 3 kali dalam seminggu). Uji hubungan antara umur dengan aktivitas fisik menggunakan uji Chi Square.

\section{Hasil Penelitian dan Pembahasan}

Hasil Penelitian

Mayoritas responden dalam penelitian ini adalah perempuan dengan jumlah 67,5\% sedangkan laki-laki berjumlah 32,5\%. Lokasi penelitian merupakan daerah urban. Keberadaan lokasi pemukiman warga berada di antara kegiatan industri seperti ready-mix plant dan pertokoan yang berada di tepi jalan raya. Kondisi wilayah sangat padat dengan rumah penduduk dan sangat jarang terlihat ruang terbuka hijau. Pada waktu tertentu, tingkat kepadatan kendaraan bermotor di jalan raya akan meningkat di lokasi penelitian karena berada di jalur perlintasan Bogor - Depok - Jakarta. 
Tabel 1. Analisis Univariat Distribusi Umur dan Karakteristik Responden Tahun 2018

\begin{tabular}{lcccc}
\hline \multicolumn{1}{c}{ Variabel } & $\begin{array}{c}\text { Rata - } \\
\text { rata }\end{array}$ & SD & Min - Maks & CI 95\% \\
\hline Umur & 41,8 & 11,8 & $17-76$ & $39,69-43,92$ \\
$\begin{array}{l}\text { Aktivitas Jalan Kaki } \\
\text { Frekuensi (per minggu) }\end{array}$ & 5,9 & 2,2 & $1-8$ & $5,38-6,35$ \\
Lama (menit/hari) & 17,5 & 23,3 & $5-120$ & $22,68-32,90$ \\
Aktivitas Joging & 1,8 & 0,9 & $1-3$ & $1,29-2,21$ \\
Frekuensi (per minggu) & 65,9 & 42 & $0,15-180$ & $43,56-88,32$ \\
Lama (menit/hari) & & & & \\
Aktivitas Bersepeda & 3,8 & 2,6 & $1-7$ & $1,06-6,60$ \\
Frekuensi (per minggu) & 40 & 43,2 & $10-120$ & $-5,38-85,38$ \\
Lama (menit/hari) & & & & $1-7$ \\
Aktivitas Senam & 2,1 & 1,9 & $1,01-3,12$ \\
Frekuensi (per minggu) & 75 & 47,4 & $15-120$ & $49,72-100,28$ \\
Lama (menit/hari) & & &
\end{tabular}

Rata-rata umur responden dalam penelitian ini berusia 41,8 tahun (tabel 1). Paling muda berusia 17 tahun dan paling tua berusia 76 tahun. Diantara aktivitas fisik yang dilakukan oleh responden paling banyak adalah jalan kaki yaitu $67 \%$ dibandingkan dengan aktivitas lainnya (tabel 2).

Rata-rata responden melakukan aktivitas jalan kaki sebanyak 5,87 kali dalam seminggu dengan lama 17,50 menit per hari atau 103 menit dalam seminggu.Diantara seluruh variabel aktivitas fisik, bersepada merupakan aktivitas yang paling banyak tidak dilakukan oleh responden di lokasi penelitian $(95,1 \%)$. Kemudian, diikuti oleh aktivitas joging dan senam dengan persentase yang sama (87\%).

Tabel 2. Analisis Univariat dan Bivariat Distribusi Rata-rata Umur Menurut Aktivitas Fisik Responden

\begin{tabular}{llllll}
\hline Aktivitas Fisik & Frekuensi (\%) & Rata-rata Umur & SD & SE & Nilai P \\
\hline Jalan Kaki & & & & & \\
Ya & $83(67,5)$ & 41,5 & 12,4 & 1,4 & $0,700^{\text {a }}$ \\
Tidak & $40(32,5)$ & 42,4 & 10,7 & 1,7 & \\
\hline Joging & & & & & \\
Ya & $16(13)$ & 33,6 & 12,8 & 3,2 & $0,003^{\text {a }}$ \\
Tidak & $107(87)$ & 43 & 11,2 & 1,1 & \\
\hline Bersepeda & & & & & \\
Ya & $6(4,9)$ & 45,8 & 8,9 & 3,6 & $0,394^{\mathrm{a}}$ \\
Tidak & $117(95,1)$ & 41,6 & 11,9 & 1,1 & \\
\hline Senam & & & & & \\
Ya & $16(13)$ & 38,6 & 12 & 3 & $0,241^{\mathrm{a}}$ \\
Tidak & $107(87)$ & 42,3 & 11,8 & 1,1 & \\
\hline$\quad$ a Uji Chi Square & & & & &
\end{tabular}


Rata-rata umur responden yang melakukan aktivitas jalan kaki adalah 41,5 tahun dengan standar deviasi 12,4 tahun, sedangkan responden yang tidak melakukan aktivitas jalan kaki, rata-rata umurnya adalah 42,4 tahun dengan standar deviasi 10,7 tahun. Hasil uji statistik didapatkan nilai $p=0,700$ yang berarti tidak terdapat perbedaan yang signifikan antara ratarata usia responden yang melakukan aktivitas jalan kaki dan tidak melakukan jalan kaki.

Rata-rata umur responden yang melakukan aktivitas joging adalah 33,6 tahun dengan standar deviasi 12,8 tahun. Pada responden yang tidak melakukan aktivitas joging, rata-rata usianya adalah 43 tahun dengan standar deviasi 11,2 tahun. Hasil uji statistik diketahui nilai $p$ $=0,003$. Hal tersebut menunjukkan bahwa terdapat perbedaan yang signifikan antara rata-rata usia responden yang melakukan aktivitas joging dan tidak melakukan joging.

Responden yang melakukan aktivitas bersepeda adalah 45,8 tahun dengan standar deviasi 8,9 tahun. Pada responden yang tidak melakukan aktivitas bersepeda, rata-rata usianya adalah 41,6 tahun dengan standar deviasi 11,9 tahun. Hasil uji statistik diketahui nilai p=0,394. Hasil tersebut menunjukkan bahwa tidak terdapat perbedaan rata-rata usia secara signifikan antara responden yang melakukan aktivitas bersepeda dan tidak melakukan bersepeda.

Aktivitas senam dilakukan oleh responden yang rata-rata berusia 38,6 tahun dengan standar deviasi 12 tahun. Selanjutnya, responden yang tidak melakukan aktivitas senam, ratarata berusia 42,3 tahun dengan standar deviasi 11,8 tahun. Hasil uji statistik diketahui nilai $\mathrm{p}=$ 0,241 . Ini menunjukkan bahwa tidak terdapat perbedaan yang signifikan antara rata-rata usia antara responden yang melakukan aktivitas senam dan tidak melakukan senam.

\section{Tabel.3. Analisis Lama Waktu Aktivitas Fisik (menit/hari) dengan Umur Responden}

\begin{tabular}{lrrcc}
\hline \multicolumn{1}{c}{ Variabel } & $\mathbf{R}$ & $\mathbf{R}^{2}$ & Persamaan Garis & Nilai P \\
\hline Lama jalan kaki & 0,053 & 0,003 & Lama (menit/hari) $=23,49+0,11$ & $0,634^{\mathrm{a}}$ \\
$\begin{array}{l}\text { Lama joging } \\
\begin{array}{l}\text { Lama } \\
\text { bersepeda }\end{array}\end{array}$ & 0,184 & 0,034 & Lama (menit/hari) $=86,25-0,60$ & $0,495^{\mathrm{a}}$ \\
$\begin{array}{l}\text { Lama senam } \\
0,422\end{array}$ & 0,178 & Lama (menit/hari) $=-53,66+2,04$ & $0,405^{\mathrm{a}}$ \\
\hline
\end{tabular}

aUji T Sampel Independen

Hubungan umur dengan lama jalan kaki dalam menit/hari menunjukkan hubungan lemah $(\mathrm{r}=0,053)$ dan berpola positif yang artinya semakin bertambah umur semakin bertambah lama aktivitas jalan kaki. Nilai koefisien dengan determinasi 0,003 menunjukkan persamaan garis regresi yang diperoleh dapat menerangkan 0,3\% variasi lama aktivitas. Hasil uji statistik didapatkan tidak terdapat hubungan signifikan antara umur dengan lama jalan kaki dengan nilai $\mathrm{p}>0,635(>0,05)$.

Hubungan umur dengan lama joging dalam menit/hari menunjukkan hubungan lemah $(\mathrm{r}=0,184)$ dan berpola negatif yang berarti semakin bertambah umur semakin berkurang lama aktivitas joging responden. Nilai koefisien dengan determinasi 0,034 menunjukkan persamaan garis regresi yang diperoleh dapat menerangkan 3,4\% variasi lama aktivitas. Hasil uji statistik memperlihatkan bahwa tidak terdapat hubungan signifikan antara umur dengan lama joging dengan nilai p $0,495(>0,05)$. 
Hubungan umur dengan lama bersepeda dalam menit/hari menunjukkan hubungan sedang $(r=0,422)$ dan berpola positif yang berarti semakin bertambah umur semakin bertambah lama aktivitas bersepeda responden. Nilai koefisien dengan determinasi 0,178 menunjukkan persamaan garis regresi yang diperoleh dapat menerangkan 17,8\% variasi lama aktivitas. Hasil uji statistik memperlihatkan bahwa tidak terdapat hubungan signifikan antara umur dengan lama bersepeda dengan nilai p 0,405 $(>0,05)$.

Hubungan umur dengan lama senam dalam menit/hari menunjukkan hubungan kuat $(\mathrm{r}=0,527)$ dan berpola negatifyang berarti semakin bertambah umur semakin berkurang lama aktivitas senam responden. Nilai koefisien dengan determinasi 0,278 menunjukkan persamaan garis regresi yang diperoleh dapat menerangkan $27,8 \%$ variasi lama aktivitas. Hasil uji statistik memperlihatkan bahwa terdapat hubungan signifikan antara umur dengan lama senam dengan nilai p $0,036(<0,05)$.

\section{Pembahasan}

Pergeseran pola hidup dari aktivitas aktif menjadi aktivitas pasif sebagai konsekuensi dari perkembangan teknologi (Azhari et al., 2009). Pada masyarakat urban seperti di Jakarta, aktivitas fisik sangat terbatas untuk dilakukan. Menurut Kawahara et.al. (2012), faktor utamanya adalah dipengaruhi oleh lingkungan. Pada lokasi penelitian, area yang dapat digunakan untuk melakukan aktivitas fisik sangat terbatas. Kondisi tersebut merupakan faktor pemungkin untuk tidak banyak melakukan pergerakan fisik. Di lokasi penelitian, faktor pemungkin tersebut adalah lingkungan seperti ruang terbuka yang nyaman untuk melakukan aktivitas fisik sangat terbatas. Melalui wawancara tidak terstruktur, warga usia lanjut enggan untuk melakukan joging dengan alasan keselamatan diri dan kekuatan fisik. Berdasarkan observasi, wilayah ini termasuk daerah yang ramai dengan aktivitas warga baik di median jalan karena kerapatan antar rumah, kepadatan kendaraan, dan kendaraan terparkir. Hal ini menjadi alasan untuk tidak atau jarang melakukan aktivitas fisik.

Aktivitas fisik paling banyak dilakukan oleh responden di Kelurahan Lenteng Agung, Jakarta Selatan adalah berjalan kaki. Kegiatan ini termasuk kategori aktivitas dengan intensitas rendah dan sedang yang dilakukan secara terus menerus. Jalan kaki merupakan kegiatan yang paling mudah dan praktis untuk dilakukan oleh masyarakat perkotaan. Dalam sebuah penelitian telah diketahui manfaat aktivitas jalan kaki bagi penderita hipertensi. Pasien dengan menderita hipertensi di sebuah rumah sakit di Dolok Sanggul memiliki pengaruh terhadap penurunan tekanan darah (sistolik maupun diastolik) dengan melakukan aktivitas jalan kaki selama 30 menit(Surbakti, 2014). Peredaran darah menjadi lebih lancar karena kaya akan oksigen serta meningkatkan elastisitas pembuluh darah dan jantung bekerja dengan normal. Endapan lemak pada dinding pembuluh darah juga menurun sehingga dapat terhindar dari arteriosklerosis. Selain itu, aktivitas jalan kaki juga berdampak positif terhadap tingkat kebugaran jasmani seseorang(Junaidi, 2011).

Umur memiliki hubungan dengan aktivitas jogging dan lama aktivitas senam. Temuan dalam penelitian ini sejalan dengan hasil penelitian Sharma dan Goodwin (2006), umur mempengaruhi intensitas seseorang untuk melakukan kegiatan fisik. Hal ini disebabkan oleh berbagai macam faktor.Dalam penelitian Sprung et.al.(2006), kekuatan otot pada jalur pernafasan manusia terbukti secara konsisten menurun seiring berjalannya umur. Bertambahnya umur akan berakibat pada penurunan fungsi dan kapasitas paru dalam menjalankan fungsinya apalagi jika tidak melakukan aktivitas fisik secara rutin (Pruthi, N., \& Multani, 2012; Sharma \& Goodwin, 2006). Pada individu yang aktif bergerak, sistem pernafasan akan tetap stabil meskipun dengan aktivitas berat. Sebaliknya, pada individu yang tidak banyak bergerak, $\mathrm{VO}_{2 \max }$ (volume maksimal $\mathrm{O}_{2}$ saat melakukan kegiatan yang intensifyang diproses 
oleh tubuh manusia) berkurang secara teratur seiring bertambahnya usia (Janssens, 2005). Penurunan faal organ transpor dan penggunaan oksigen yang terjadi akibat bertambahnya umur sehingga mempengaruhi kinerja paru-jantung (kardiorespirasi) (Pribadi, 2015). Ditambah lagi, penyakit yang berkaitan dengan sistem pernafasan menduduki peringkat teratas selama tiga tahun $(2015,2016$, dan 2017) di lokasi penelitian (Puskemas Jagakarsa, 2017). Hal ini tentunya menjadi faktor lain yang harus diteliti pada penelitian selanjutnya untuk mengetahui faktor penyebab gangguan pernafasan yang terjadi di lokasi penelitian.

\section{Kesimpulan}

Aktivitas jalan kaki adalah kegiatan yang lebih tinggi persentasenya dibandingkan dengan aktivitas lainnya. Hal ini menandakan bahwa jalan kaki lebih banyak dilakukan oleh responden. Aktivitas ini sangat mudah dilakukan pada daerah perkotaan yang memiliki ruang terbuka yang terbatas. Dalam penelitian ini, hanya aktivitas joging yang berhubungan secara statistik dengan umur. Perlu dilakukan upaya untuk peningkatkan fasilitas bagi warga agar dapat melakukan berbagai jenis aktivitas fisik berdasarkan kelompok umur, Kemudian, promosi dan edukasi mengenai aktivitas fisik juga perlu digalakkan untuk meningkatkan kesadaran dan partisipasi masyarakat.

\section{Ucapan Terima Kasih}

Para peneliti mengucapkan terima kasih atas bantuan dan dukungan oleh berbagai pihak terhadap penyusunan penelitian ini. 


\section{Daftar Pustaka}

Azhari, Ishak, S., \& Wilujeng, L. K. (2009). Hubungan Aktivitas Fisik Kebugaran Fisik dan Imej Tubuh dengan Kejadian Obesitas. Buletin Penelitian Kesehatan, 12(3), 319-329.

Balitbang Kemkes RI. (2013). Riset Kesehatan Dasar (RISKESDAS) 2013. Jakarta: Badan Penelitian dan Pengembangan Kesehatan Kementerian Kesehatan RI. Diambil dari http://www.depkes.go.id/resources/download/general/Hasil Riskesdas 2013.pdf

Janssens, J.-P. (2005). Aging of the respiratory system: Impact on pulmonary function tests and adaptation to exertion. Clinics in Chest Medicine, 26(3), 469-484. https://doi.org/10.1016/j.ccm.2005.05.004

Junaidi, S. (2011). Pembinaan Fisik Lansia Melalui Aktivitas Olahraga Jalan Kaki. Jurnal Media Ilmu Keolahragaan Indonesia, 1(1), 17-21. https://doi.org/2088-6802

Kawahara, J., Tanaka, S., Tanaka, C., Aoki, Y., \& Yonemoto, J. (2012). Daily Inhalation Rate and Time-Activity/Location Pattern in Japanese Preschool Children. Risk Analysis, 32(9), 15951604. https://doi.org/10.1111/j.1539-6924.2011.01776.x

Minh, H. Van, Pocock, N. S., Chaiyakunapruk, N., Chhorvann, C., Duc, H. A., Hanvoravongchai, P., ... Sychareun, V. (2015). Progress toward universal health coverage in ASEAN. Global Health Action, 8, 1-12. https://doi.org/10.3402/gha.v8.27368

Novanda, A. W., \& Dwiyanti, E. (2014). Hubungan Pemenuhan Kebutuhan Kalori Kerja dengan Produktivitas di Pabrik Sepatu. The Indonesian Journal of Occupational Safety and Health, 3(2), 117-127. Diambil dari http://journal.unair.ac.id/download-fullpapersk3ecac57ec96full.pdf

Ortlepp, J. R., Metrikat, J., Albrecht, M., \& Maya-Pelzer, P. (2004). Relationship between Physical Fitness and Lifestyle Behaviour in Healthy Young Men. The European Society of Cardiology, 11(3), 192-200. https://doi.org/10.1097/01.hjr.0000131578.48136.85

Palar, C. M., Wongkar, D., \& Ticoalu, S. H. R. (2015). Manfaat Latihan Olahraga Aerobik Terhadap Kebugaran Fisik Manusia. Jurnal e-Biomedik, 3(1), 316-321. Diambil dari http://ejournal.unsrat.ac.id/index.php/ebiomedik/article/view/7127

Pribadi, A. (2015). Pelatihan Aerobik Untuk Kebugaran Paru Jantung Bagi Lansia. Journal of Chemical Information and Modeling, 11(July), 64-76. https://doi.org/10.1017/CB09781107415324.004

Pruthi, N., \& Multani, N. . (2012). Influence of Age on Lung Function Tests. Journal of Exercise Science and Physiotherapy, 8(1), 1-6. https://doi.org/DOI: 10.18376//2012/v8i1/67598

Purwanto. (2011). Dampak Senam Aerobik terhadap Daya Tahan Tubuh dan Penyakit. Jurnal Media Ilmu Keolahragaan Indonesia, 1(7), 1-9.

Puskemas Jagakarsa. (2017). Laporan Tahunan Data Kesakitan. Jakarta Selatan.

Sharma, G., \& Goodwin, J. (2006). Effect of Aging on Respiratory System Physiology and Immunology. Clinical interventions in aging, 1(3), 253-260. https://doi.org/10.2147/ciia.2006.1.3.253

Skloot, G. S. (2017). The Effects of Aging on Lung Structure and Function. Clinics in Geriatric 
Medicine, 33(4), 447-457. https://doi.org/10.1016/j.cger.2017.06.001

Sprung, J., Gajic, 0., \& Warner, D. 0. (2006). Review Article: Age Related Alterations in Respiratory Function - Anesthetic Considerations. Canadian Journal of Anesthesia, 53(12), 1244-1257.

Sulistiono, A. A. (2015). Prediksi Aktivitas Fisik Sehari-hari, Umur, Tinggi, Berat Badan dan Jenis Kelamin Terhadap Kebugaran Jasmani Siswa SMP di Banjarmasin. Jurnal Pendidikan dan Kebudayaan, 20(3), 380-389. Diambil dari http://jurnaldikbud.net/index.php/jpnk/article/view/152

Surbakti, S. (2014). Pengaruh Latihan Jalan Kaki 30 Menit Terhadap Tekanan Darah Pada Pasien Hipertensi. Pengabdian Kepada Masyarakat, 20 (September 2014), 1-15.

Suter, E., Ma, B., Tschopp, A., Wanner, H. U., Wenk, C., Gutzwiller, F., ... Jog-, E. S. (1990). Effects of Self-Monitored Jogging on Physical Fitness, Blood Pressure and Serum Lipids : A Controlled Study in Sedentary Middle-Aged Men. International Journal of Sprots Medicine, $11,425-432$.

WHO. (2018). Prevalence of Insufficient Physical Activity. Diambil 23 November 2018, dari http://www.who.int/gho/ncd/risk_factors/physical_activity_text/en

Woo, J. S., Derleth, C., Stratton, J. R., \& Levy, W. C. (2006). The Influence of Age, Gender, and Training on Exercise Efficiency. Journal of the American College of Cardiolog, 47(5), 10491057. https://doi.org/10.1016/j.jacc.2005.09.066 